\title{
An Odd-Even Sum Labeling of Jellyfish and Mushroom Graphs
}

\author{
Rusdan Nurhakim* and Budi Harianto \\ Program Studi Matematika, Fakultas Sains dan Teknologi \\ Universitas Islam Negeri Syarif Hidayatullah Jakarta \\ Email: rafanrusdan10@gmail.com
}

\begin{abstract}
A graph $G(V, E)$ with $p$ vertices and $q$ edges called graph odd-even sum if there exists an injective function $f$ from $V$ to $\{ \pm 1, \pm 2, \pm 3, \ldots, \pm(2 p-1)\}$ such that induced a bijection $f *(u v)=f(u)+$ $f(v)$ as label of edge and $u, v \in V$ forms the set $\{2,4, \ldots, 2 q\}$, and $f$ is called odd-even sum labeling. There are three criteria of graphs that can be labeled by this labeling, they are undirected, no loops, and finite for every edges and vertex. Jellyfish $J_{m, n}$ graph and Mushroom $M r_{m}$ graph have the criteria. So in this paper will be showed that the Jellyfish and Mushroom graphs can be labeled by this labeling.

Keywords: odd-even sum graph; odd-even sum labeling; Jellyfish and mushroom graphs.
\end{abstract}

\begin{abstract}
Abstrak
Graf $G(V, E)$ dengan banyak titik $p$ dan sisi $q$ dikatakan graf jumlah ganjil-genap jika terdapat suatu fungsi injetif $f$ dari $V$ ke $\{ \pm 1, \pm 2, \pm 3, \ldots, \pm(2 p-1)\}$ sehingga bijektif $f *(u v)=f(u)+f(v)$ merupakan label sisi dengan $u, v \in V$ membentuk himpunan bilangan $\{2,4, \ldots, 2 q\}$, dengan $f$ merupakan pelabelan jumlah ganjil-genap. Kriteria graf yang dapat dilabeli oleh pelabelan jumlah ganjilgenap ada tiga, yaitu graf yang tidak berarah, tidak memiliki loop, dan terhingga, baik secara sisi maupun titik. Graf Jellyfish $J_{m, n}$ dan Mushroom $M r_{m}$ memenuhi ketiga kriteria tersebut. Pada tulisan ini akan ditunjukkan bahwa kedua graf tersebut dapat dilabeli dengan pelabelan jumlah ganjil-genap.

Kata kunci: graf jumlah ganjil-genap; pelabelan jumlah ganjil-genap; graf Jellyfish dan graf Mushroom.
\end{abstract}

\section{INTRODUCTION}

Let $G=(V, E)$ be simple and finite graph with $p$ vertices and $q$ edges. Grap $G$ is said to be an odd-even sum graph if there exists an injective function $f: V \rightarrow\{ \pm 1, \pm 2, \pm 3, \ldots, \pm(2 p-1)\}$ such that induced a bijection $f^{*}: E \rightarrow\{2,4,6, \ldots, 2 q\}$ with $f^{*}(u v)=f(u)+f(v), \forall u v \in E$. The function $f$ is called an odd-even sum labeling of $G$ [1].

Harary [2] defined a sum graph. Ponraj et al. [3] proved that a graph is pair sum labeling. Ramya et al. [4] proved that a graph is skolem even-vertex-odd difference mean labeling. Arockiaraj et al. [5] introduced the odd-sum labeling of sum subdivision graphs. Monika and Murugan [1] proved that a path $P_{n}, n \geq 2$, a star $K_{1, n}$, and caterpillar graph are odd-even sum labeling. In this paper, we proved that a Jellyfish and Mushroom graphs are odd-even sum graphs. 


\section{DEFINITION}

In this section we define Jellyfish graph and Mushroom graphs. A Jellyfish $J_{m, n}$ graph for $m, n \geq 1$ is a graph with a set of vertex $V=\left\{u, x, v, y, x_{i}, y_{j} \mid\right.$ for $i=1,2,3, \ldots, m, j=$ $1,2,3, \ldots, n\}$, a set of edges $E=\{u x, u v, u y, v x, v y\} \cup\left\{x x_{i} \mid i=1,2, \ldots, m\right\} \cup\left\{y y_{j} \mid j=1,2, \ldots, n\right\}$ [6]. Jellyfish $J_{m, n}$ graph has no loop or double edges, and undirected. An example of Jellyfish $J_{m, n}$ graph is shown in Figure 1.

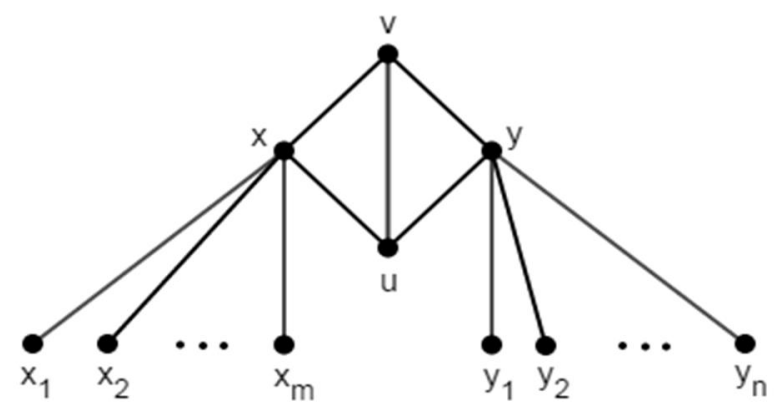

Figure 1. Jellyfish $\boldsymbol{J}_{\boldsymbol{m}, \boldsymbol{n}}$ graph.

Mushroom $M r_{m}$ graph for $m \geq 2$ is graph with a set of vertex $V=\left\{v_{i}, w, u_{j} \mid i=1,2,3, \ldots, m\right.$, $j=1,2,3, \ldots, n\}$ and with a set of edges $E=\left\{w v_{i} \mid i=1,2, \ldots, m\right\} \cup\left\{w u_{j} \mid j=1,2, \ldots, m\right\} \cup$ $\left\{v_{i} v_{i+1} \mid i=1,2, \ldots, m-1\right\}$. This graph has no loop or double edges, and so undirected. An example of Mushroom $M r_{m}$ graph is shown in Figure 2.

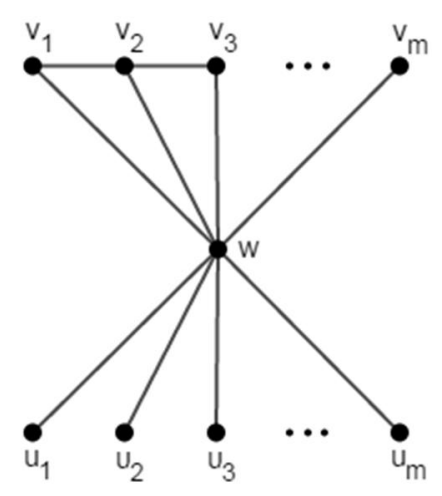

Figure 2. Mushroom $\boldsymbol{M} \boldsymbol{r}_{\boldsymbol{m}}$ graph.

In this paper will be discussed regarding odd-even sum labeling for Jellyfish graph $J_{m, n}$ for $m, n \geq 1$ but $m=n$, and Mushroom graph $M r_{m}$ for $m \geq 2$.

\section{RESULTS}

In this section, we show that Jellyfish $J_{m, n}$ graph has an odd-even sum labeling. Two important results in this paper will be shown as follows. 
Theorem 3.1. Jellyfish $J_{m, n}$ graph for $m, n \geq 1$ is an odd-even sum graph.

Proof. Let $V\left(J_{m, n}\right)=\left\{u, x, v, y, x_{i}, y_{j} \mid i=1,2,3, \ldots, m ; j=1,2,3, \ldots, m\right\}$ and $E\left(J_{m, n}\right)=$ $\{u x, u v, u y, v x, v y\} \cup\left\{x x_{i} \mid i=1,2,3, \ldots, m\right\} \cup\left\{y y_{j} \mid j=1,2, \ldots, n\right\}$. Then $|V(J m, n)|=2 m+$ 4 and $|E(J m, n)|=2 m+5$. Let $f: V(J m, n) \rightarrow\{ \pm 1, \pm 3, \ldots, \pm 2(2 m+4)-1\}$ be defined as follows:

$$
\begin{array}{ll}
f(v)=-(2 m+1), & \\
f(u)=2 m+3, & \\
f(x)=2 m+5, & \\
f(y)=2 m+7, & i=1,2,3, \ldots, m ; \\
f\left(x_{i}\right)=2 i+1 ; & j=1,2,3, \ldots, n . \\
f\left(y_{j}\right)=-(2 j-1) ; &
\end{array}
$$

Let $f^{*}$ be the induced edge labeling of $f$, then

$$
\begin{aligned}
& f^{*}(v u)=2 ; \\
& f^{*}(v x)=4 ; \\
& f^{*}(v y)=6 ; \\
& f^{*}(u x)=2(2 m+4) ; \\
& f^{*}(u y)=2(2 m+5) ; \\
& f^{*}\left(x x_{i}\right)=2 m+2 i+6 ; \quad i=1,2,3, \ldots, m ; \\
& f^{*}\left(y y_{j}\right)=2 m-2 j+8 ; \quad j=1,2,3, \ldots, n .
\end{aligned}
$$

The induce edge labels are $2,4,6, \ldots, 2(2 m+5)$ which are all distinct. Hence Jellyfish $J_{m, n}$ graph for $\mathrm{m}, n \geq 1$ is an odd-even sum graph.

Theorem 3.2. Mushroom $M r_{m}$ graph for $m \geq 2$ is an odd-even sum graph.

Proof. Let $V\left(M r_{m}\right)=\left\{v_{i}, w, u_{j} \mid i=1,2,3, \ldots, m, j=1,2,3, \ldots, m\right\} \quad$ and $\quad\left(M r_{m}\right)=\left\{w v_{i} \mid i=\right.$ $1,2,3, \ldots, m\} \cup\left\{w u_{j} \mid j=1,2,3, \ldots, m\right\} \cup\left\{v_{i} v_{i+1} \mid i=1,2,3, \ldots,(m-1)\right\}$. Then $|V(M r m)|=2 m+$ 1 and $|E(M r m)|=3 m-1$. Let $f: V(M r m) \rightarrow\{ \pm 1, \pm 3, \ldots, \pm(2(2 m+1)-1)\}$.

Case (i) $m$ is odd,

$$
\begin{array}{lrl}
f\left(v_{2 i-1}\right)=m+2 i-2 ; & i=1,2,3, \ldots, \frac{m+1}{2}, \\
f\left(v_{2 i}\right)=3 m+2 i ; & i=1,2,3, \ldots, \frac{m-1}{2}, \text { for } m \geq 3, \\
f(w)=-1, & j=1,2,3, \ldots, \frac{m+1}{2}, \\
f\left(u_{2 j-1}\right)=2 m+2 j-1 ; & j=1,2,3, \ldots, \frac{m-3}{2}, \text { for } m \geq 5, \\
f\left(u_{2 j}\right)=2 j+1 ; & \\
f\left(u_{m-1}\right)=4 m+1 . &
\end{array}
$$

Let $f^{*}$ be the induced edge labeling of $f$, then

$$
\begin{array}{ll}
f^{*}\left(w v_{2 i-1}\right)=m+2 i-3 ; & i=1,2,3, \ldots, \frac{m+1}{2}, \\
f^{*}\left(w v_{2 i}\right)=3 m+2 i-1 ; & i=1,2,3, \ldots, \frac{m-1}{2}, \text { for } m \geq 3, \\
f^{*}\left(w u_{2 j-1}\right)=2 m+2 j-2 ; & j=1,2,3, \ldots, \frac{m+1}{2}, \\
f^{*}\left(w u_{2 j}\right)=2 j ; & j=1,2,3, \ldots, \frac{m-3}{2}, \text { for } m \geq 5, \\
f^{*}\left(w u_{m}\right)=4 m, &
\end{array}
$$




$$
f^{*}\left(v_{i} v_{i+1}\right)=4 m+2 i ; i=1,2,3, \ldots,(m-1) .
$$

Case (ii) $m$ is even,

$$
\begin{aligned}
& f\left(v_{2 i-1}\right)=m+2 i-1 ; i=1,2,3, \ldots, \frac{m}{2}, \\
& f\left(v_{2 i}\right)=3 m+2 i-1 ; i=1,2,3, \ldots, \frac{m}{2} \text {, } \\
& f(w)=-1 \\
& f\left(u_{2 j-1}\right)=2 m+2 j-1 ; \quad j=1,2,3, \ldots, \frac{m}{2} \\
& f\left(u_{2 j}\right)=2 j+1 ; \quad j=1,2,3, \ldots, \frac{m-2}{2} \text {, for } m \geq 4 \text {, } \\
& f\left(u_{m}\right)=4 m+1 \text {. }
\end{aligned}
$$

Let $f^{*}$ be the induced edge labeling of $f$, then

$$
\begin{array}{ll}
f^{*}\left(w v_{2 i-1}\right)=m+2 i-2 ; & i=1,2,3, \ldots, \frac{m}{2}, \\
f^{*}\left(w v_{2 i}\right)=3 m+2 i-2 ; & i=1,2,3, \ldots, \frac{m}{2}, \\
f^{*}\left(w u_{2 j-1}\right)=2 m+2 j-2 ; & j=1,2,3, \ldots, \frac{m}{2}, \\
f^{*}\left(w u_{2 j}\right)=2 j ; & j=1,2,3, \ldots, \frac{m-2}{2}, \text { for } m \geq 4, \\
f^{*}\left(w u_{m}\right)=4 m, & \\
f^{*}\left(v_{i} v_{i+1}\right)=4 m+2 i ; i=1,2,3, \ldots,(m-1) .
\end{array}
$$

The induce edge labels are $2,4,6, \ldots, 2(3 m-1)$ which are all distinct. Hence Mushroom $M r_{m}$ graph for $m \geq 2$ is an odd-even sum graph.

\section{CONCLUSION}

Based on the results of subsection before, can be obtained two theorems that the authors call Theorem 3.1, states that Jellyfish $J_{m, n}$ graph for $m, n \geq 1$ is an odd-even sum graph and Theorem 3.2 states that Mushroom $M r_{m}$ graph for $m \geq 2$ is an odd-even sum graph.

\section{REFERENCES}

[1] K. Monika and K. Murugan, "Odd-even Sum Labeling of Some Graphs," International Journal of Mathematics and Soft Computing, vol. 7 No. 1, pp. 57-63, 2017.

[2] F. Harary, "Sum Graphs and Difference Graphs," Congressus Numerantium, vol. 72, pp. 101-108, 1990.

[3] R. Ponraj, J. V. X. Parthipan, and R. Kala, "Some Results on Pair Sum Labeling of Graphs," International J. Math. Combin, vol. 4, pp. 53-61, 2010.

[4] D. Ramya, R. Kalaiyarasi and P. Jeyanthi, "Skolem Odd Difference Mean Graphs," Journal of Algorithms and Computation, vol. 45, pp. 1-12, 2014.

[5] S. Arockiaraj, P. Mahalakhsmi, and P. Namasivayam, "Odd Sum Labeling of Some Subdivision Graphs," Kragujevac Journal of Mathematics, vol. 38(1), pp. 203-222, 2014.

[6] S-M. Lee and A. N-T. Lee, "On Super Edge-magic Graphs with many Odd Cycles," Congressus Numerantium, pp. 65-80, 2003. 
An Odd-Even Sum Labeling of Jellyfish and Mushroom Graphs

91 | InPrime: Indonesian Journal of Pure and Applied Mathematics 